\title{
A külföldi munkavállalói jövedelem és a munkavállalói hazautalós statisztikai számbavétele
}

\section{Bujnóczki Anett,}

a Központi Statisztikai Hivatal vezetőtanácsosa

E-mail: Anett.Bujnoczki@ksh.hu
A tanulmány a magyar munkaerőpiac külföldi szegmensét mutatja be, ezen belül a munkából származó jövedelmek, hazautalások elszámolásával, becslési módszertanával és az eljárás során felhasznált adatforrások ismertetésével foglalkozik.

TÁRGYSZÓ:

Külföldi munkavállalói jövedelem.

Munkavállalói hazautalás.

ESA 2010.

DOI: 10.20311/stat2017.06.hu0599 
Közismert, hogy a Magyarországról munkavállalási céllal külföldre indulók száma emelkedő tendenciát mutat. Ez indokolja, hogy növekvő érdeklődés övezi a kivándorlók bérével és az itthon maradt családtagok részére hazautalt összegekkel kapcsolatos statisztikákat. A médiában megjelenő hírek, információk sokszor tévesen, félrevezetően közlik és magyarázzák az adatokat, részben azért, mert nem ismerik pontosan a témával kapcsolatos fogalmakat. Az elemzések gyakran szinonimaként említik a munkavállaló jövedelmet, a nettó, „kézhez kapott” bért és a munkavállalói hazautalást. Számos esetben tapasztaljuk, hogy a KSH-ba (Központi Statisztikai Hivatal) érkező adatkérések megválaszolásához előzetesen pontosítani kell a felhasználó által kért adat tartalmát. A félreértésekre az is okot adhatott, hogy eddig nem állt rendelkezésre kellő információ és metaadat.

Azért tartjuk fontosnak és időszerünek a definíciók és a módszertan bemutatását, hogy ezzel a következőkben elkerülhetővé tegyük a téves értelmezések előfordulását.

\section{Módszertani alapfogalmak}

A KSH Nemzeti számlák főosztálya 2008 óta állítja össze a rezidens és a nem rezidens egységek közötti gazdasági müveleteket tartalmazó külföld számlák teljes sorozatát. A külföld számla alapvető fogalmi és módszertani keretét az ESA 2010 (European system of accounts - a nemzeti számlák európai rendszere) ${ }^{1}$ szabályozza. Fontos tisztázni, mi is a munkavállalói jövedelem, mit nevezünk hazautalásnak és kik az alanyai Az ESA 2010 megkülönbözteti a munkavállalói jövedelem és a munkavállalói hazautalás fogalmát. A különbség megértéséhez elsőként a rezidens és a nem rezidens egységeket kell definiálni, ugyanis ebből érthetővé válik, hogy a két tétel nem használható szinonimaként. A definíció szerint „A teljes gazdaság meghatározása rezidens egységek révén történik. Egy egység akkor tekinthető egy ország rezidens egységének, ha elsődleges gazdasági érdekeltségének központja az adott ország gazdasági területére esik - azaz az adott ország területén hosszabb ideig (legalább egy évig) folytat gazdasági tevékenységet...” (ESA 2010 1.61). „A háztartások - föld- és épülettulajdonosi minőségüket kivéve - annak a gazdasági terület rezidens

\footnotetext{
${ }^{1}$ Az Európai Parlament és a Tanács 549/2013/EU rendelete (2013. május 21.) az Európai Unió-beli nemzeti és regionális számlák európai rendszeréről. Az Európai Unió Hivatalos Lapjának honlapján a hivatalos európai uniós nyelveken is elérhető a rendelet. http://eur-lex.europa.eu/legal-content/HU/TXT/?uri= OJ:L:2013:174:TOC
} 
egységei, ahol elsődleges gazdasági érdekeltségük központja található. Rezidensnek minősülnek akkor is, ha bizonyos (egy évnél rövidebb) időt külföldön töltenek...” (ESA 2010 2.10). Ez a meghatározás az alapja, hogy különbséget tudjunk tenni külföldön végzet munkából származó jövedelmen belül a munkavállalói jövedelem és a munkavállalói hazautalás között. Másként mutatjuk ki a számlákban, ha egy fiatal 6 vagy 18 hónapra megy Angliába dolgozni. Amennyiben 6 hónapig dolgozik az adott országban, a teljes jövedelme munkavállalóiként, az elsődleges jövedelmek között jelenik meg a külföld számlában. Azonban 18 hónapos külföldön tartózkodás esetén, a módszertan alapján már Angliában számít rezidensnek, így nem lehet alanya a magyar GNI-ba ${ }^{2}$ (gross national income - bruttó nemzeti jövedelem) beszámító munkavállalói jövedelemnek. Ekkor másodlagos jövedelemként, a folyó transzferek között számoljuk el a nettó béréből hazautalt részt.

A munkavállalói jövedelem alatt ,a munkáltató által a munkavállaló részére, az elszámolási időszak alatt elvégzett munkája ellenértékeként fizetett valamennyi pénzbeli vagy természetbeni díjazás értendö.” (ESA 2010 4.02) Ez a tétel a nettó béreken felül magában foglalja az szja-t (személyijövedelem-adó), a munkaadó, illetve a munkavállaló által fizetett tb- (társadalombiztosítási) hozzájárulásokat, járulékokat is.

Míg a munkavállalói jövedelem az elsődleges jövedelmek egyik alkategóriája, addig a munkavállalói hazautalások a háztatások közötti transzfereken belüli „ebböl” tétel. „A határokon átnyúló személyes transzferek ${ }^{3}$ - amelyek háztartások közötti transzferek - azért érdekesek, mert azon országok számára, ahonnan nagy számú munkaerő áramlik hosszú távra külföldre, fontos nemzetközi finanszírozási forrásként szolgálnak. A személyes transzferek tartalmazzák a hosszú távon külföldön dolgozók hazautalásait, vagyis azokét, akik megváltoztatják lakóhelyüket, és így egy másik gazdaságban lesznek rezidensek.” (ESA 2010 18.52)

A három alapfogalom ismeretén túl, az adott tétel könnyebb azonosításához segítséget nyújthat, ha megvizsgáljuk, hogy kik (vagy mely szektorok) között zajlik le a tranzakció. A külföld számla részeként minden esetben egy rezidens és egy nem rezidens fél közötti gazdasági müveletet kell elszámolni. Az egy éven belül más országban dolgozó munkavállaló (háztartások szektor) munkája ellenértékének, a munkaadó (jellemzően nem pénzügyi vállalatok, vagy pénzügyi vállalatok szektor)

\footnotetext{
${ }^{2}$ GNI: A bruttó (vagy nettó) nemzeti jövedelem (piaci áron) a rezidens gazdasági egységek teljes elsődleges jövedelmét jelenti, amelyek a következők: a munkavállalói jövedelem, a termelési és importadók egyenlege, a tulajdonból származó jövedelem (követelés mínusz fizetendő), a bruttó (vagy nettó) müködési eredmény és a bruttó (vagy nettó) vegyes jövedelem.

„A bruttó nemzeti jövedelem (piaci áron) egyenlő a GDP és a rezidens gazdasági egységek által a nem rezidens gazdasági egységeknek fizetett elsődleges jövedelem különbségével, hozzáadva ehhez a rezidens gazdasági egységek által a külföldtől kapott elsődleges jövedelmet.

A nemzeti jövedelem nem a termeléssel, hanem a jövedelemmel kapcsolatos fogalom, amelyet sokkal inkább indokolt nettó formában kifejezni, azaz az állóeszköz-felhasználás értéke nélkül.” (ESA 2010 8.94)

${ }^{3}$ A személyes transzfer a munkavállalók hazautalásainál tágabb kategória, mivel a háztartások közötti folyó transzferek is részét képezik.
} 
által fizetett teljes összegét az elsődleges jövedelmek ${ }^{4}$ között mutatjuk ki, a munkavállalói jövedelemnél. Az egy évet meghaladóan más országban foglalkoztatott munkavállalói jövedelemének egy részét - két háztartás (háztartások szektor) közötti tranzakciót - másodlagos jövedelemként, ${ }^{5}$ a munkavállalók hazautalásai soron számoljuk el. Az 1. táblázat a munkavállalói jövedelem és a munkavállalók hazautalásainak ismérveit foglalja össze. ${ }^{6}$

1. táblázat

A munkavállalói jövedelem és a munkavállalók hazautalásai

\begin{tabular}{l|c|c}
\hline \multicolumn{1}{c|}{ Megnevezés } & \multicolumn{1}{|c}{ Munkavállalói jövedelem } & Munkavállalók hazautalásai \\
\hline \multirow{2}{*}{ Rezidensség } & $\begin{array}{c}\text { Egy évnél rövidebb ideig más országban } \\
\text { foglalkoztatott }\end{array}$ & $\begin{array}{c}\text { Egy évnél hosszabb ideig más országban } \\
\text { foglalkoztatott }\end{array}$ \\
\hline Tartalom & $\begin{array}{c}\text { A jövedelem teljes összegének elszámolása } \\
\text { (a bérből fizetett adókkal, munkaadói és } \\
\text { munkavállalói járulékokkal együtt) }\end{array}$ & A nettó bér hazautalt részének elszámolása \\
\hline Tranzakció alanyai & Munkaadó $\square$ munkavállaló & Háztartás $\square$ háztartás \\
\hline
\end{tabular}

\section{Rövid történeti áttekintés}

A külföld számla összeállítását megelőzően a GNI számításához a külfölddel kapcsolatosan csak az elsődleges jövedelmek tételeit közölték, melyhez akkoriban az adatokat az MNB (Magyar Nemzeti Bank) szolgáltatta.

A teljes külföld számlát 2008-tól publikáljuk, melyben a KSH új becslési módszert dolgozott ki a külföldet érintő munkavállalói jövedelemre (továbbá annak adóira és járulékaira), a munkavállalók hazautalásaira, illetve a külföldre menő, onnan származó nyugdíjra. Az új eljárás lényegesen magasabb értékre becsülte a külfölddel kapcsolatos

\footnotetext{
${ }^{4}$ „Az „elsődleges jövedelem” az a jövedelem, amelyet a rezidens egységek kapnak, amiért közvetlenül részt vesznek a termelési folyamatban, valamint az a jövedelem, amelyet a pénzügyi eszköz vagy a természeti erőforrások birtokosa kap cserébe azért, hogy a pénzügyi eszközt vagy a természeti erőforrásokat egy másik gazdasági egység rendelkezésére bocsátja.” (ESA 2010 8.22)

5 „A ,jövedelmek másodlagos elosztása” számla azt mutatja, hogy egy gazdasági szektor elsődleges jövedelem egyenlegét hogyan osztják fel újra, mint: folyó jövedelem-, vagyon- és más adók, társadalombiztosítási járulékok és juttatások (a természetbeni társadalmi transzferek kivételével), valamint egyéb folyó transzferek." (ESA 2010 8.30)

${ }^{6}$ Az éves munkavállalói jövedelemre, illetve a munkavállalók hazautalásaira vonatkozó adatok elérhetőek a KSH (stADAT) és az Eurostat (például az adatbázis) honlapján: http://www.ksh.hu/docs/hun /xstadat/xstadat_eves/i_qp015d.html, http://ec.europa.eu/eurostat/data/database
} 
munkából származó jövedelmet, mint amilyen volt a megelőző években az MNB által a fizetési forgalomban elszámolt, pénzforgalmi adatok alapján számított adat.

A külföldről kapott munkavállalói jövedelem és a munkavállalói hazautalások adatforrásai 2014-ben módosultak. Korábban a külföldön dolgozók létszámához használt munkaerőmérleg és az egy före jutó átlagbér megállapítására szolgáló ILO(International Labour Organization - Nemzetközi Munkaügyi Szervezet) adatbázis helyett kerestünk megbízhatóbb, rendszeresen rendelkezésre álló adatokat. A kialakított módszertan szerint - melyet 2009-ig vezettünk vissza - a létszám meghatározása a külföldi telephelyen dolgozókra vonatkozó MEF- (munkaerö-felmérés-) adatok alapján történik (korábban a kevésbé részletes munkaerőmérleget vettük alapul), míg az egy före jutó átlagbért az Eurostat adatbázisából elérhető adatokból állapítjuk meg. 2015-ben a 2011. évi népszámlás alapján újrasúlyozott MEF-adatokat építettük be a munkavállalói jövedelem becslésébe (visszavezetés 2011-ig). 2016-ban a külföldre fizetett munkavállalói jövedelem és munkavállalói hazautalás módszertanában történt felülvizsgálat (visszavezetés 2011-ig). Az adatforrások (például az szja) a korábbival megegyezők, azonban az adatok minőségének javítása érdekében az alapadatok feldolgozási folyamatába különböző szürési feltételeket építettünk (lásd az 5.3. Magyarországon foglalkoztatott külföldi rezidensek munkavállalói jövedelme címü alfejezetet).

A továbbiakban a külföldről kapott munkavállalói jövedelem és a munkavállalók hazautalásai, illetve a külföldre fizetett munkavállalói jövedelem és a munkavállalók külföldre történő hazautalásai adatok összeállítása során alkalmazott szabályokat és definíciókat, illetve az elszámolás jelenlegi módszertanát mutatjuk be.

Itt jegyezzük meg, hogy tapasztalataink alapján nagyobb érdeklődés irányul a külföldön szerzett jövedelem és a külföldről kapott hazautalás nagyságára, ezért a példák, diagramok többnyire ezekre a tételekre vonatkoznak.

\section{A külföld számla és a fizetési mérleg}

A külfölddel szembeni tranzakciókat a külföld számla mellett a Magyar Nemzeti Bank által összeállított fizetési mérleg ${ }^{7}$ is tartalmazza. Amíg a KSH statisztikájára vonatkozó szabályokat a korábban említett ESA 2010 szabályozza, addig az MNB által publikált fizetési mérleg alapvető elöírásait a „Fizetési mérleg és külfölddel szembeni befektetési pozíció” címü kézikönyv (6. kiadás [BPM6] $)^{8}$. A két módszer-

\footnotetext{
${ }^{7}$ INTERNATIONAL MONETARY FUND [2009]: Balance of Payments and International Investment Position Manual. Sixth Edition (BPM6). Washington, D.C. Table A5.2. https://www.imf.org/external/pubs/ft/bop/ 2007/pdf/bpm6.pdf

${ }^{8} \mathrm{https} / / /$ www.imf.org/external/pubs/ft/bop/2007/pdf/bpm6.pdf
} 
tani leírás szerint alkalmazott fogalmi keret összhangban van egymással. A 2. táblázat a külföld szektor számlait és a fizetési mérleget mutatja be. A két statisztika tételeinek felépítésében, sorrendiségében van némi eltérés, azonban sorai külön-külön megfeleltethetők egymásnak.

A külföld szektor számlái és a fizetési mérleg

\begin{tabular}{|c|c|}
\hline Külföld szektor számlái & Fizetési mérleg \\
\hline Termékek és szolgáltatások külföld számlája & I. Folyó fizetési mérleg \\
\hline $\begin{array}{l}\text { B.11 Termékek és szolgáltatások külkereskedelmi } \\
\text { egyenlege }\end{array}$ & 1. A Áruk és szolgáltatások \\
\hline $\begin{array}{l}\text { Elsődleges jövedelmek és folyó transzferek külföld } \\
\text { számlája }\end{array}$ & 1.B Elsődleges jövedelmek \\
\hline D.1 Munkavállalói jövedelem & 1.B.1 Munkavállalói jövedelem \\
\hline D.4 Tulajdonból származó jövedelem összesen & 1.B.2 Befektetések jövedelmei \\
\hline \multirow[t]{2}{*}{$\begin{array}{l}\text { D.2 Termelési és importadók } \\
\text { D.3 Támogatások }\end{array}$} & 1.B.3 Egyéb elsődleges jövedelmek \\
\hline & 1.C Másodlagos jövedelmek \\
\hline D.5 Folyó jövedelem-, vagyon- stb. adók & Jövedelem-, vagyon- és egyéb adók \\
\hline D.61 Nettó társadalombiztosítási hozzájárulások & Társadalombiztosítási járulékok \\
\hline D.621 Pénzbeni társadalmi juttatások & Pénzbeni társadalmi juttatások \\
\hline D.7 Egyéb folyó transzferek & $\begin{array}{l}\text { Nettó nem életbiztosítási díjak } \\
\text { Nem életbiztosítási kárterítések } \\
\text { Nemzetközi együttmüködéshez kapcsolódó } \\
\text { folyó transzferek } \\
\text { Egyéb viszonzatlan folyó transzferek }\end{array}$ \\
\hline D.752 Háztartások közötti folyó transzferek & $\begin{array}{l}\text { Személyi transzferek (rezidens és nem rezi- } \\
\text { dens háztartások között) }\end{array}$ \\
\hline D.752W Munkavállalók hazautalásai & Munkavállalók hazautalásai \\
\hline D.8 Nyugdíjjogosultságok változása miatti korrekció & $\begin{array}{l}\text { 1.C.3 Nyugdíjjogosultságok változása miatti } \\
\text { korrekció }\end{array}$ \\
\hline Tökeszámla & 2. Tökemérleg \\
\hline D.9 Töketranszferek & $\begin{array}{l}\text { 2.1 Nem termelt, nem pénzügyi javak forgalma, } \\
\text { egyenleg }\end{array}$ \\
\hline $\begin{array}{l}\text { NP Nem termelt eszközök beszerzésének és eladásának } \\
\text { egyenlege }\end{array}$ & 2.2 Töketranszferek \\
\hline Pénzügyi számla & 3. Pénzügyi mérleg (nettó követelés) \\
\hline
\end{tabular}

Forrás: KSH stADAT, MNB (http://www.mnb.hu/statisztika/statisztikai-adatok-informaciok/adatokidosorok/viii-fizetesi-merleg-kozvetlen-tokebefektetesek-kulfolddel-szembeni-allomanyok/fizetesi-merlegkulfolddel-szembeni-allomanyok/bpm6-modszertan-szerinti-adatok). 
A két intézmény között hosszú évek óta szoros a munkakapcsolat, közös cél a két statisztika harmonizálása.

A KSH végzi a munkavállalói jövedelemre és a munkavállalók hazautalásaira vonatkozó becslési eljárás kialakítását (az MNB tájékoztatása és véleményezése mellett), valamint az adatok folyamatos összeállítását, és azokat az MNB rendelkezésére bocsátja. Az adatokat mindkét hivatal a saját statisztikájában publikálja. Az eltérő revíziós politika miatt az idősorokban azonban előfordul, előfordulhat eltérés.

A fizetési mérleg az MNB honlapján ennél összevontabb tételek szerint csoportosítva jelenik meg, az Eurostat adatbázisában a részletes tételek is láthatók, azonban az ESA-kódok szerint jelölve.

\section{A külföld számla}

A külföld számla tehát a rezidens és a nem rezidens egységek közötti gazdasági műveletek elszámolását mutatja be, a külföld szempontjából figyeli a gazdasági eseményeket. Ezek alapján, a külföld számlán megjelenő források a teljes gazdaság számára felhasználást jelentenek és fordítva.

A külföld számlák sorozata a következök szerint csoportosítható:

a) termékek és szolgáltatások külföld számlája,

b) az elsődleges jövedelmek és folyó transzferek külföld számlája,

c) felhalmozási számlák,

- tőkeszámla,

- pénzügyi számla,

- az eszközök egyéb változásai számla,

d) vagyonmérlegek.

Jelen téma kapcsán a folyószámlák áttekintése lényeges. A folyószámlák a termékek és szolgáltatások, valamint az elsődleges jövedelmek és folyó transzferek ${ }^{9}$ (másodlagos jövedelmek) számlájából épül fel. A folyó számlák egyenlegező tétele a folyó külső egyenleg.

A külföld számlát továbbvezetve, a folyó külső egyenleg és a tőketranszferek egyenlegének összegeként kapjuk meg a nettó vagyonváltozás folyó külső egyenleg

\footnotetext{
${ }^{9}$ Folyó transzfer valamennyi, az egyes szektorok közötti jövedelem- és vagyonadó, valamint a tbhozzájárulások, a pénzbeni társadalmi juttatások, illetve az egyéb folyó transzfer.
} 
és tőketranszferek miatt egyenlegező tételt, melyet a nem termelt eszközök beszerzésének és eladásának egyenlegével korrigálva jutunk el a nettó hitelnyújtás/nettó hitelfelvétel egyenlegező tételhez.

\subsection{A munkavállalói jövedelem és a munkavállalók hazautalásainak elszámolása a külföld számlán}

A munkavállalói jövedelem (D.1), mint elsődleges jövedelem - mint a GNI nagyságát befolyásoló tétel - jelenik meg a folyószámlákban. A külföldröl kapott, illetve a külföldre fizetett munkavállalói jövedelem elemei:

a) bérek és keresetek (D.11);

b) munkaadók társadalombiztosítási járulékai (D.12).

A másodlagos jövedelmek között, ellentétes száron kerül elszámolásra a jövedelemadó (D.5 Folyó jövedelem-, vagyon- stb. adók), valamint a munkaadók és a munkavállalók kötelező tb-hozzájárulásai (D.61 nettó társadalombiztosítási hozzájárulások). Ezen korrekciókkal jutunk el a bruttó szemléletben elszámolt munkavállalói jövedelemtől a nettó bérig.

Az egy évnél hosszabb ideig külföldön dolgozó munkavállalói hazautalása a folyó transzferek között szerepel.

3. táblázat

A munkavállalói jövedelem és a munkavállalói hazautalás elszámolása a külföld számlában, 2015 (millió Ft)

\begin{tabular}{l|c|c}
\hline \multicolumn{1}{c|}{ ESA-kód és megnevezése } & \multicolumn{2}{c}{2015. évi } \\
\cline { 2 - 3 } & felhasználás & forrás \\
\hline Termékek és szolgáltatások külföld számlája & & \\
\hline P.6 Termékek és szolgáltatások exportja & 30846183 & \\
\hline P.61 Termékek exportja & 24665843 & \\
\hline P.62 Szolgáltatások exportja & 6180340 & \\
\hline P.7 Termékek és szolgáltatások importja & & 27816705 \\
\hline P.71 Termékek importja & & 23309202 \\
\hline P.72 Szolgáltatások importja & & 4507503 \\
\hline B.11 Termékek és szolgáltatások külkereskedelmi egyenlege & -3029478 & \\
\hline
\end{tabular}

(A táblázat folytatása a következö oldalon.) 


\begin{tabular}{|c|c|c|}
\hline \multirow{2}{*}{ ESA-kód és megnevezése } & \multicolumn{2}{|c|}{ 2015. évi } \\
\hline & felhasználás & forrás \\
\hline \multicolumn{3}{|l|}{ Elsődleges jövedelmek és folyó transzferek } \\
\hline B.11 Termékek és szolgáltatások külkereskedelmi egyenlege & & -3029478 \\
\hline D.1 Munkavállalói jövedelmek & 1036550 & 150269 \\
\hline D.11 Bérek és keresetek & 863792 & 134455 \\
\hline D.2 Termelési és importadók & & 53117 \\
\hline D.3 Támogatások & 452643 & \\
\hline D.4 Tulajdonból származó jövedelem & 1713595 & 4594229 \\
\hline D.41 Kamat & 573561 & 1198900 \\
\hline D.42 Vállalatok felosztott jövedelme & 363300 & 1750140 \\
\hline D.43 Külföldi közvetlen tőkebefektetés újrabefektetett jövedelme & 756470 & 1638799 \\
\hline D.44 Egyéb befektetésből származó jövedelem & 20264 & 6390 \\
\hline D.5 Folyó jövedelem-, vagyon- stb. adók & 8650 & 183845 \\
\hline D.61 Nettó társadalombiztosítási hozzájárulások & 26649 & 332560 \\
\hline D.621 Pénzbeni társadalmi juttatások & 30401 & 14613 \\
\hline D.7 Egyéb folyó transzferek & 557679 & 462582 \\
\hline Ebből: munkavállalói hazautalás & 197883 & 38395 \\
\hline D.8 Nyugdíjjogosultságok változása miatti korrekció & 0 & 0 \\
\hline B.12 Folyó külső egyenleg & -1064430 & \\
\hline \multicolumn{3}{|l|}{ Nettó vagyon változása folyó külső egyenleg és tőketranszfer számla miatt } \\
\hline B.12 Folyó külső egyenleg & & -1064430 \\
\hline D.9 Tőketranszferek & 1703362 & 77576 \\
\hline $\begin{array}{l}\text { B.10.1 A nettó vagyon változása folyó külső egyenleg és tőketranszferek } \\
\text { miatt (B.12 + D.9) }\end{array}$ & -2690216 & \\
\hline \multicolumn{3}{|l|}{ Nem pénzügyi eszközök beszerzése } \\
\hline $\begin{array}{l}\text { B.10.1 A nettó vagyon változása folyó külső egyenleg és tőketranszfer } \\
\text { miatt (B.12 + D.9) }\end{array}$ & & -2690216 \\
\hline NP Nem termelt eszközök beszerzésének és eladásának egyenlege & -33278 & \\
\hline B.9 Nettó hitelnyújtás (+) / nettó hitelfelvétel (-) (B.10.1-NP) & -2656938 & \\
\hline
\end{tabular}

Forrás: KSH, stADAT (http://www.ksh.hu/docs/hun/xstadat/xstadat_eves/i_qp015d.html).

A 3. táblázat a külföld számla tételeit - kiemelve a munkavállalói jövedelmet és munkavállalói hazautalásokat - mutatja be. A felhasználás oldalon a külföldröl kapott, míg a forrás oldalon a külföldre fizetett tételek vannak elszámolva.

A munkavállalói jövedelmet és a munkavállalók hazautalásait tehát a külföld számla - külön soron - tartalmazza. Azonban a két tétel sem külön-külön, sem együtt nem ad teljes körủ információt arról, hogy valójában, összességében mennyit 
utalhatnak haza családtagjaiknak a külföldön dolgozók. Az előzőekből annyit ismerhetünk, hogy

- az egy éven belül külföldön foglalkoztatott magyarnak vagy a Magyarországon dolgozó külföldi munkavállalónak mekkora a bruttó szemléletben elszámolt munkavállalói jövedelme. A tétel tartalmazza a munkavégzés helyén fizetett adókat és járulékokat, valamint az ezek levonása után (nettósítás) a „kézhez kapott” bérből a munkavégzés helyén finanszírozott fogyasztást (étkezés, ruházkodás, albérlet, utazás, szórakozás stb.) is.

- egy éven túl külföldön foglalkoztatott magyar vagy Magyarországon dolgozó külföldi állampolgár az adott országban rezidenssé válva, a nettó fizetéséböl, saját fogyasztási és megtakarítási igényeit kielégítve mennyit utal „otthon maradt” családtagjai részére.

\subsection{Hazautalás jellegű egyéb mutatók}

Két számított mutatót érdemes megemlíteni, amelyek az ismertetett adatokból részben vagy egészben - elóállíthatók:

1. A Világbank minden évben közzéteszi az ún. bilateral remittance matrix (kétoldalú hazautalási mátrix) ${ }^{10}$ táblát, amely a ki- és a bevándorlók „hazautalásait” tartalmazza. Ezek közel 220 ország zárt rendszerben publikált adatai. A mutató országonként, országbontásban a munkavállalói jövedelem egészének és a személyes transzferek ${ }^{11}$ együttes adatát tartalmazza. A táblázat lábjegyzete arra enged következtetni, hogy az adatbázisba a fizetési mérlegben publikált adatok felhasználásával kerültek a Magyarországra vonatkozó számok. Nagyságrendileg ezzel egyeznek meg az adatok, azonban vélhetőleg némi korrekciót hajtottak végre a világszintű konzisztencia biztosítása érdekében.

$\mathrm{Az}$ ezen mátrix elemzésére vonatkozóan megjelenő sajtócikkek messzemenő következtetéseket vonnak le. Visszautalnék az előző bekezdésre, mely szerint a munkavállalói jövedelem és a munkavállalók

\footnotetext{
${ }^{10} \mathrm{http} / / /$ www.worldbank.org/en/topic/migrationremittancesdiasporaissues/brief/migration-remittances-data ${ }^{11}$ Lásd a 3. lábjegyzetet.
} 
hazautalás összege nem azt az információt nyújtja, mint amit a Világbank címe alapján vélhetünk, valójában nem nevezhetjük hazautalásnak. Magyarországon a kivándorlók ,hazautalásainak” jelentős részét a munkavállalói jövedelem teszi ki. Azaz a GNI részét képező elsődleges jövedelemtétel, a külföldről kapott munkavállalói jövedelem az egy évnél rövidebb ideig külföldön foglalkoztatottak jövedelmét tartalmazza, azokét, akik - jelen esetben - Magyarországon rezidensek. Ez a munkából származó jövedelmek legtágabb kategóriája. Ebből kell levonni a munkaadók tb-járulékait, a fennmaradó összeg a bruttó bérek és keresetek értéke. A másodlagos jövedelmeknél elszámolt, munkavállaló által „,fizetett" szja, illetve munkaadói és munkavállalói tb-hozzájárulás levonása után kapott (kézhez kapott) összeg a nettó bérek és keresetek, amely a becslés alapján 55-57 százaléka (a 2011és 2015 közötti időszakban) a munkavállalói jövedelemnek. A nettó bérekből és keresetekből a külföldön foglalkoztatott a munkavégzés helyén fogyasztásra is költ (például albérletet fizet, élelmiszert vásárol, ruházkodik, közlekedik, esetleg szórakozik, nevezetességeket látogat stb.). Ezek alapján ezt a munkavállalói jövedelmet nem nevezhetjük hazautalásnak. A Világbank által publikált mátrix másik összetevője a személyes átutalás, amely valóban egy hazautalás jellegü tétel, azonban ez a közzétett adatnak csak egy kis hányadát képezheti. Ez az arány - tehát a munkavállalók hazautalásait a munkavállalói jövedelem és a munkavállalók hazautalásai összegéhez viszonyítva - a KSH becslése szerint a 2011 és 2015 közötti időszakot vizsgálva 14-16 százalék. (Lásd a 3. táblázatot.)

2. Létezik egy, a BPM6 által részletezett és az ESA 2010-ben is említett kiegészíto tétel, a „személyes hazautalások” (personal remittances). A mutató a külföld számla tételeiből előállítható és a háztartások tényleges hazautalásait talán legmegbízhatóbban tükrözi. Tartalmazza az adókkal és járulékokkal, valamint a munkavállaló munkavégzés helyéhez köthető, fogyasztási kiadással csökkentett jövedelmét, a személyi transzfereket (ennek része a munkavállalói hazautalás), illetve a háztartások közötti tőketranszfereket. Ez a mutató tehát magában foglalja az egy éven belül, illetve egy éven túl más országban foglalkoztatottak tényleges hazautalásait.

Szükebb kategóriája a teljes hazautalásoknak (total remittances and transfers to NPISHs) a személyes hazautalások. Ahogy azt a 4. táblázat mutatja, a fizetési mérleg kézikönyvben (BPM6) részletezett teljes hazautalás tartalmazza a pénzbeni társadalmi juttatásokat, valamint a háztartásokat segítő nonprofit intézményeknek nyújtott folyó és tőketranszfereket. 
Hazautalások

\begin{tabular}{|c|c|c|c|c|c|}
\hline \multicolumn{6}{|c|}{ Teljes hazautalás és a háztartásokat segítő nonprofit intézményeknek nyújtott transzferek $(a+b+c+d+e+f)$} \\
\hline \multicolumn{4}{|c|}{ Teljes hazautalás $(a+b+c+d)$} & $e$ & $f$ \\
\hline \multicolumn{3}{|c|}{ Személyes hazautalások $(a+b+c)$} & $d$ & \multirow[b]{3}{*}{$\begin{array}{c}\text { Háztartásokat } \\
\text { segítő nonprofit } \\
\text { intézményeknek } \\
\text { nyújtott folyó } \\
\text { transzferek }\end{array}$} & \multirow[b]{3}{*}{$\begin{array}{c}\text { Háztartásokat } \\
\text { segítő nonprofit } \\
\text { intézményeknek } \\
\text { nyújtott tőke- } \\
\text { transzferek }\end{array}$} \\
\hline$a$ & $b$ & $c$ & & & \\
\hline $\begin{array}{c}\text { Személyi } \\
\text { transzferek } \\
\text { (folyó transzfe- } \\
\text { rek része) }\end{array}$ & \begin{tabular}{|c|} 
Munkavállalói \\
jövedelemadók- \\
kal és társadalmi \\
juttatásokkal, \\
valamint a közle- \\
kedési \\
és a turizmus \\
költségeivel \\
csökkentve
\end{tabular} & $\begin{array}{c}\text { Háztartások } \\
\text { közötti tőke- } \\
\text { transzfer }\end{array}$ & $\begin{array}{l}\text { Pénzbeni társa- } \\
\text { dalmi juttatás }\end{array}$ & & \\
\hline
\end{tabular}

Forrás: InTERnATIONAL MONETARy Fund [2009]: Balance of Payments and International Investment Position Manual. Sixth Edition (BPM6). Washington, D.C. Table A5.2. https://www.imf.org/external/ pubs/ft/bop/2007/pdf/bpm6.pdf

Látható, hogy többféle megközelítés, számítás lehetséges a „hazautalás” tétel kimutatására, azonban mindenképpen fontos ismerni az alapadatok tartalmát. Különböző felhasználási célra más és más információk lehetnek szükségesek.

\begin{tabular}{l|l}
\multicolumn{2}{c}{ Hazautalás jellegü mutatók tartalma } \\
\hline $\begin{array}{c}\text { Személyes hazautalás } \\
\text { (BPM6) }\end{array}$ & \multicolumn{1}{c}{$\begin{array}{c}\text { Ki- és bevándorlók átutalásai } \\
\text { (Világbank) }\end{array}$} \\
\hline $\begin{array}{l}\text { A munkavégzés helyéhez kapcsolódó fogyasztási } \\
\text { kiadással csökkentett munkavállalói jövedelem a } \\
\text { fizetett adókkal és járulékokkal }\end{array}$ & Munkavállalói jövedelem \\
\hline $\begin{array}{l}\text { Személyi transzferek (ennek része az egy évnél hosz- } \\
\text { szabb ideig külföldön dolgozó munkavállalók haza- } \\
\text { utalásai) }\end{array}$ & $\begin{array}{l}\text { Személyi transzferek (ennek része az egy évnél hosz- } \\
\text { szabb ideig külföldön dolgozó munkavállalók haza- } \\
\text { utalásai) }\end{array}$ \\
\hline Háztartások közötti tőketranszferek & \\
\hline
\end{tabular}

Forrás: Világbank-adatok (http://www.worldbank.org/en/topic/migrationremittancesdiasporaissues/brief/ migration-remittances-data; https://openknowledge.worldbank.org/bitstream/handle/10986/23743/ 9781464803192.pdf). 


\subsection{Hazautalás}

A definíciók, a módszertan ismeretében feltehető a kérdés, vajon mely tételeket beleértve a külföld számlában elszámolt, illetve azokból számítható mutatókat nevezhetjük tényleges hazautalásnak vagy hazautalás jellegü tételnek? A válaszadásban a 6. táblázat nyújthat segítséget.

6. táblázat

\begin{tabular}{c|c|c}
\multicolumn{3}{c}{ Hazautalások és hazautalás jellegü tételek } \\
\hline Hazautalás jellegü tételek & $\begin{array}{c}\text { Ténylegesen } \\
\text { hazautalt összeg? }\end{array}$ & Magyarázat \\
\hline $\begin{array}{c}\text { Munkavállalói jövedelem } \\
\begin{array}{c}\text { Személyi transzferek (tartalmazza } \\
\text { a munkavállalók hazautalásait) }\end{array}\end{array}$ & nem & $\begin{array}{c}\text { Mert bruttó szemléletben elszámolt mutató, tartal- } \\
\text { mazza a háztartás kiadásait, utazási költségeit }\end{array}$ \\
\hline $\begin{array}{c}\text { Háztartások közötti tőketranszferek } \\
\text { Személyes hazautalások } \\
\text { (personal remittance) (BPM6) }\end{array}$ & igen & igen \\
$\begin{array}{c}\text { Ki- és bevándorlók hazautalásai } \\
\text { (migrant remittance) (Világbank) }\end{array}$ & részben & $\begin{array}{c}\text { Mert bruttó szemléletben elszámolt mutató, tartal- } \\
\text { mazza a háztartás kiadásait, utazási költségeit }\end{array}$ \\
\hline
\end{tabular}

Vegyük sorra! A munkavállalói jövedelem bruttó szemléletű, amely az adókkal, járulékokkal, kiadásokkal (étkezés, albérlet, ruházkodás, szórakozás stb.), utazási költséggel nincs csökkentve. Ezért ez nem nevezhetö hazautalásnak. A munkavállalók hazautalásait tartalmazó személyi transzfer jellemzően hazautalás jellegü tétel, ugyanígy a háztartások közötti tőketranszferek (például a hagyaték) is. A személyes hazautalások a háztartások tényleges hazautalásait tükröző mutató (ebben az esetben a munkavállalói jövedelmet nettósítjuk, a munkavállalási célú - a külföld számlán a turizmus és személyszállitási költségek között elszámolt - kiadásokat levonjuk). Ezek mellett tartalmazza a munkavállalói hazautalásokat, illetve a háztartások közötti tőketranszfereket.

A ki- és bevándorlók hazautalásai sem adnak megfelelő visszajelzést a hazautalásokra vonatkozóan, hiszen minden negatívum felsorolható, ami a munkavállalói jövedelemnél. A Világbank mátrixának szerkezetére tekintettel, tehát a zárt rendszer teljesülése érdekében - tükörstatisztika, illetve az egységes adatforrás és módszertan hiányában - a fizetési mérlegből rendelkezésre álló adatok korrekciója elengedhetetlen. A személyi transzfereket azonban tartalmazza, melyek hazautalás jellegü tételek. 


\section{Becslési eljárások}

A következőkben a külföldröl kapott és külföldre fizetett munkavállalói jövedelemre és munkavállalók hazautalásaira vonatkozó becslési eljárásokat mutatjuk be.

Felmerülhet a kérdés az országok közötti adatcserére vonatkozóan. Az Osztrák Statisztikai Hivatal minden évben megküldi és kéri a szezonális, illetve a határ menti ingázókra vonatkozó magyar adatokat. Eddigi tapasztalat azonban, hogy az osztrákoktól kapott adatok jóval alacsonyabbnak bizonyulnak, mint amit a magyar statisztika használ.

\subsection{A külföldön foglalkoztatott magyar rezidensek munkavállalói jövedelme}

A jelenleg használt becslési eljárást 2008-ban alakítottuk ki, majd 2014-ben az adatforrások felülvizsgálatát végeztük el. A külföldön foglalkoztatottak éves munkavállalói jövedelmének becsléséhez két fö adatforrás áll rendelkezésre: az Eurostat adatbázisa és a MEF-adatok.

\subsubsection{A külföldön foglalkoztatott magyar rezidensek száma}

A külföldön dolgozó magyar rezidensek számának meghatározása - megfelelő adatgyüjtés, tükörstatisztika, illetve országok közötti egységes nyilvántartás hiányában - nagyon nehéz feladat. Fontos kritérium az évek közötti összehasonlíthatóság biztosítása érdekében, hogy az adatforrás folyamatosan, konzisztensen elérhető legyen. Problémát jelenthet továbbá, hogy a külföld számlában a munkavállalói jövedelem vs. munkavállalók hazautalásai szétválasztásához elengedhetetlen ismerni a külföldön tartózkodás időtartamát (egy éven belüli - egy éven túli).

A jelenleg alkalmazott módszertan szerint a külföldön dolgozó magyar rezidensek létszámának meghatározásához a MEF-re támaszkodunk, amelyben a külföldi telephelyen dolgozókra, elsősorban külföldre ingázókra vonatkozó információ rendszeresen rendelkezésre áll. „A MEF-ben külföldön dolgozóként a felkeresett háztartások olyan foglalkoztatott tagjai szerepelnek, akik a napi munkavégzésük helyszíneként Magyarország határain kívül található telephelyet adtak meg." ${ }^{12}$ A MEF egy rendszeres, konzisztens, nagymintás (mintegy 35 ezer háztartást érintő) felvétel.

${ }^{12}$ LAKATOS J. [2015]: Külföldön dolgozó magyarok, Magyarországon dolgozó külföldiek. Statisztikai Szemle. 93. évf. 2. sz. 93-112. old. 
Különféle célzott felvételek és projektek (például a Mikrocenzus 2016 Nemzetközi vándorlás kiegészítő kérdốve, „Miből élünk” felvétel, SEEMIG-projekt [Managing Migration and its Effects in South-East Europe - A migráció és a migrációs hatások kezelése Délkelet-Európában]) keretében törekvések vannak a külföldön élő és dolgozó magyarok létszámának, illetve jövedelemének felmérésére. Ezek azonban kismintás egyszeri felvételek, melyek validálási, visszajelzési célra alkalmazhatók, kevésbé lehet ezeket beépíteni a rendszeresen elvégzendő becslési eljárásba.

\subsubsection{Munkavállalói jövedelem}

Az Eurostat adatbázisában található a bruttó átlagkeresetre vonatkozó olyan adatforrás, amely rendszeresen, nagy megbízhatósággal rendelkezésre áll. Az egy före jutó bruttó átlagkereset nemzetgazdasági ág szerinti bontásban meghatározható az adott nemzetgazdasági ághoz tarozó bérek és keresetek, valamint foglalkoztatotti létszám hányadosaként.

A MEF a külföldi telephelyen foglalkoztatottak létszámát a munkavégzés országa és a megkérdezett munkahelyének nemzetgazdasági ág szerinti bontásban szolgáltatja.

7. táblázat

A MEF szerint külföldi telephelyen foglalkoztatottak létszáma, 2011-2015

\begin{tabular}{l|r|r|r|r|r}
\hline \multirow{2}{*}{ Külföldi telephely } & \multicolumn{1}{c|}{2011.} & 2012. & 2013. & 2014. & 2015. \\
\cline { 2 - 7 } & \multicolumn{3}{c}{ év } & \multicolumn{4}{c}{} \\
\hline Külföldi telephelyen foglalkoztatottak létszáma (fö) & 61373 & 80389 & 97459 & 99741 & 111108 \\
\hline Ebből: & & & & & \\
\hline Ausztria & 22889 & 29820 & 44759 & 44102 & 52684 \\
\hline Nagy-Britannia & 8200 & 8931 & 8293 & 6503 & 9309 \\
\hline Németország & 13682 & 23771 & 28630 & 29723 & 31328 \\
\hline
\end{tabular}

A becslés során a négy legkeresettebb célország adatait vizsgáljuk, melyek Ausztria, Egyesült Királyság, Németország és Olaszország. A bruttó átlagkereset meghatározásához a részletes számításokat ezen országokra állítjuk össze, a továbbiakra a felsoroltak bruttó átlagkeresetének átlagát alkalmazzuk. Az így kapott nemzetgazdasági ág szerinti átlagkereseteket beszorozzuk az adott évre vonatkozó MEF munkaügyi statisztika külföldön foglalkoztatottainak számával. Feltételezzük, hogy a külföldön munkát vállaló magyarok az adott ország állampolgárainak bére alatt keresnek. Köszönhető ez többek között az egy éven belüli, rövid idejű munkavállalásnak vagy a tapasztalat hiányának, esetleg a bizonytalan nyelvtudás- 
nak stb. Ezért az adott ország ágazatos átlagbérét 0,9-es szorzóval vesszük figyelembe.

A D.1 munkavállalói jövedelem a D.11 bruttó bérek és keresetek, illetve a D.12 munkaadók társadalombiztosítási hozzájárulásai tételek összege. Hosszú idősoron megvizsgáltuk az említett négy releváns ország, valamint az EU28-, EU27-, és EU15-államok munkaadóinak tb-hozzájárulásait. Ezek alapján, minden év vonatkozásában 20 százalékban állapítottuk meg a munkaadó által fizetett tényleges társadalombiztosítási hozzájárulás (D.12) mértékét. A D.12 tétel kulcsa és összege megegyezik a másodlagos jövedelmeknél elszámolt D.611 munkaadók társadalombiztosítás járulékaival.

A külföld számlán a D.61 tételben - a fogadó ország munkaadója által fizetett tbjárulékon túl - el kell számolni a magyar munkavállaló összes kötelezettségét, melyet a fogadó ország kormányzata által fenntartott adó- és társadalombiztosítási rendszer számára befizetett. A munkavállalók társadalombiztosítási hozzájárulásai (D.613) kulcsának megállapításához - tekintettel arra, hogy az Eurostat adatbázisában rendelkezésre álló adatok vizsgálata ettől számottevő különbséget nem mutatott - a mindenkori magyarországi arányokat alkalmazzuk. Hasonlóképpen a magyar munkavállalók által befizetett személyi jövedelemadó (D.51) esetén is a magyar arányokat vesszük figyelembe.

1. ábra. A külföldön dolgozó magyar állampolgárok jövedelmének alakulása, 1995-2015

Milliárd forint

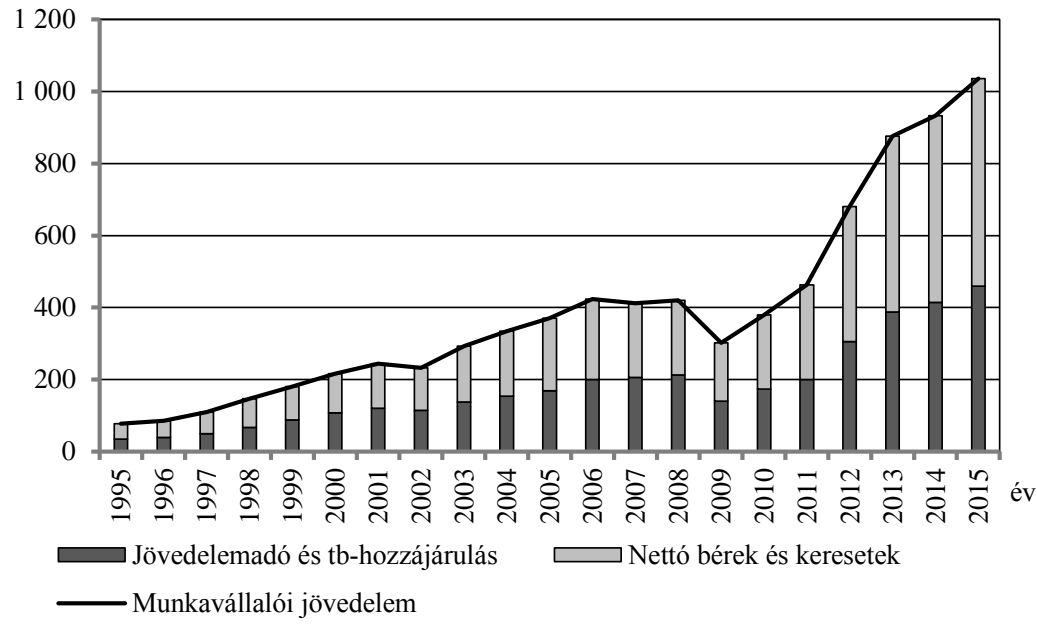

Az ábrán látható, hogy a munkavállalói jövedelemhez viszonyítjuk a nettó bért és az adókat, járulékokat. Az utóbbi öt évben a nettó bér a munkavállalói jövedelem 55-57 százaléka, míg a bruttó bérhez viszonyítva a nettó bér 66-68 százalék. 


\subsection{A külföldről származó munkavállalói hazautalások}

Az egy évnél hosszabb ideig külföldön foglalkoztatott magyar munkavállaló tehát az adott országban válik rezidenssé, így a külföld számla az ő munkavállalói jövedelemét már nem tartalmazza. Azonban a munkavállaló hazautalásait a magyar háztartásnak másodlagos jövedelemként mutatjuk ki. A becslési eljárás során a következő adatforrásokat használjuk:

- a KSH külföldről kapott munkavállalói jövedelem alapján számított egy före jutó nettó átlagbér- és keresetadatát;

- az Eurostat háztartások egy före jutó végső fogyasztási kiadási adatait;

- az Eurostat-MEF egy éven túl foglalkoztatottak létszámadatát.

A külföldről kapott munkavállalói jövedelem alapján számított egy före jutó nettó átlagbér- és keresetadat esetében - feltételezve, hogy a tartósan külföldön dogozó munkavállaló azonos munkavállalói jövedelemmel rendelkezik, mint a munkát adó ország más rezidens foglalkoztatottja - eltekintünk az ideiglenesen külföldön dolgozók munkavállalói jövedelembecslésénél alkalmazott 0,9-es szorzótól.

A tartósan külföldön dolgozók fogyasztási kiadásainak becslése során, a négy kiemelt referencia ország egy före jutó végső fogyasztási kiadásainak átlaga helyett a teljes EU-átlagot használjuk. Ennek oka, hogy Németország, Ausztria és az Egyesült Királyság egy före jutó fogyasztási kiadás adatai magasan átlagon felüliek.

A nettó bérek, keresetek és a végső fogyasztási kiadás egy fơre jutó különbségét tekintjük megtakarításnak. Ezt az összeget beszorozzuk az egy éven túl munkát vállalók létszámával.

Az egy éven túl munkát vállalók létszámát az Eurostat honlapjáról vesszük, ott a tagországok népességszámán belül külön kimutatják a más tagországok adott országban élő állampolgárait. A magyar állampolgárok számából levonjuk a munkavállalói jövedelemszámításhoz használt, az egy éven belül külföldi telephelyen foglalkoztatottak létszámát, melynek adatforrása a MEF.

Tekintettel arra, hogy az Eurostat honlapján található adat az adott országban élö összes magyar állampolgár számát fejezi ki (függetlenül attól, hogy dolgozik-e, vagy küld-e Magyarországra pénzt, illetve ha utal, a megtakarításának milyen részét), a munkavállalói hazautalások összegét az előzők szerint becsült összes megtakarítás 50 százalékában állapítjuk meg.

A külföldön dolgozó magyar rezidensek munkavállalói jövedelme - mint GNI-t növelő tétel - növekedése dinamikusabb ütemet mutat, mint a munkavállalók hazautalásai. 2009-rôl 2010-re 26, majd 2010-röl 2011-re 22 százalékkal emelkedett. A növekedés mértéke 2012-ben 47 százalékot tett ki, mely nagyrészt annak köszönhető, 
hogy jóval több magyar állampolgár dolgozott külföldön. A munkavállalási célú kiutazás 2013-ról 2014-re csökkent, mérsékelve a munkavállalói jövedelem növekedési ütemét. A külföldön dolgozó magyarok hazautalásai a 2009-es és 2010-es közel azonos szintet követően, folyamatosan emelkedő tendenciát mutat. Törés 2010-ről 2011-re, majd 2013-ról 2014-re figyelhető meg, a létszámadatok csökkenésének következtében, amely tompítja a növekedési ütemét.

2. ábra. A külföldröl kapott munkavállalói jövedelem

és a külföldröl érkezö munkavállalói hazautalások, 2009-2015

Milliárd forint

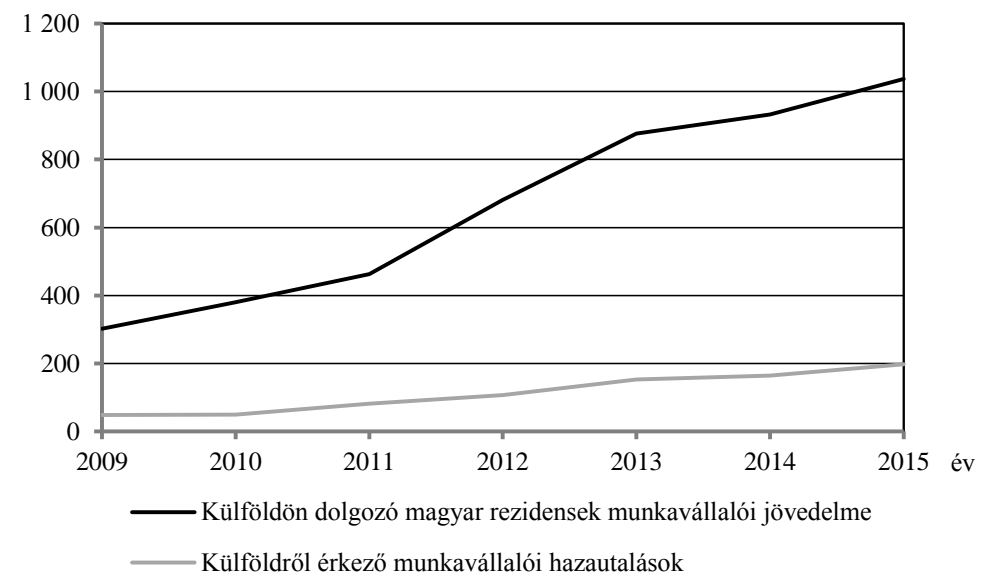

\subsection{Magyarországon foglalkoztatott külföldi rezidensek munkavállalói jövedelme}

A Magyarországon dolgozó külföldi állampolgárok munkavállalói jövedelembecslési módszertanának felülvizsgálatára 2016-ban került sor. A forrás korábban is az szja-bevallás volt, mindössze pontosítottuk a felhasznált adatok körét.

A munkavállalói jövedelem meghatározásakor a következőket vesszük figyelembe:

1. a regisztrált külföldi állampolgárok munkavállalói jövedelmét;

2. a nem regisztrált külföldi állampolgárok rejtett munkavállalói jövedelmét;

3. az illegális munkából származó munkavállalói jövedelmet.

A regisztrált külföldi állampolgárok munkavállalói jövedelmének számításához az adatok forrása a külföldi állampolgárok szja-bevallása. Ebből a béradatok közvet- 
lenül rendelkezésre állnak. Korrekciókat végzünk annak érdekében, hogy megkülönböztessük a magyar rezidensnek minősülő és nem minősülő személyeket. Például, ha egy román állampolgár az szja-bevallásának mezőgazdasági őstermelőkre vonatkozó mezőit tölti ki, feltételezhető, hogy magyarországi rezidensként kell elszámolni, hiszen egy nem rezidens állampolgár Magyarországon nem lehet őstermelő.

Öt országot vizsgálunk részletesen: Horvátországot, Romániát, Szlovákiát, Szerbiát, valamint Ukrajnát. Állampolgáraikról feltételezzük, hogy határ menti ingázók, vagy szezonális munkát vállalók, ezért őket alapesetben külföldi rezidensként kezeljük. Tapasztalataink szerint a bevallások többségét az említett öt országból származó munkavállalók nyújtják be.

Nehezen választható szét a külföldre fizetett munkavállalói jövedelem és a munkavállalók hazautalásainak adatforrása. Három egymást követő év szja-adatainak vizsgálata és feldolgozása szükséges ahhoz, hogy végleges információ álljon rendelkezésre külön a munkavállalói jövedelemre és külön a hazautalásra.

A regisztrált külföldi rezidens munkavállalók létszám-, bruttó bér- és keresetadatát a következőképpen becsüljük (zárójelben azok az évszámok szerepelnek, amelyek adatait a vonatkozási év adatainak becsléséhez 2016 szeptemberében felhasználtunk):

1. Kizárjuk azokat, akik a kritériumok ${ }^{13}$ szerint magyar rezidensnek minősülnek, mivel bérük nem képezheti a munkavállalói jövedelemnek részét.

2. Előzetes adat (2015. vonatkozási év):

a) öt releváns ország béradatai (2015. év);

b) egyéb országokból érkező külföldiekre vonatkozó béradat a megelőző év (2014. év) végleges adatával (3. b) pont) megegyező.

3. Végleges adat (2014. vonatkozási év):

a) öt releváns ország béradatai (2014. év);

b) azon egyéb országokból érkező külföldiek, akik a tárgyévet megelőző (2013. év) és a tárgyévet követő (2015. év) években nem adtak be szja-t. Ebből megállapítható, hogy egymást követő két évben bevallott bérrel rendelkezett-e a külföldi állampolgár. Csak abban az esetben számoljuk el a munkavállalói jövedelmét, amennyiben egy adott évben nyújtott be szja-t, mivel ebben az esetben számít külföldi rezidensnek.

Azokat a külföldi állampolgárokat, akik nem tartoznak az előző kategóriába, magyar rezidenseknek tekintjük, és jövedelmükböl becsüljük a munkavállalók hazautalásait.

\footnotetext{
${ }^{13}$ Családi kedvezményre jogosult, mezőgazdasági őstermelőként jelent stb.
} 
Minden olyan külföldi állampolgár létszáma és jövedelme (kivéve azt, aki nem jelentett béradatot), aki Magyarországon szja-bevallást nyújtott be, megjelenik a munkavállalói jövedelem vagy a munkavállalók hazautalásai között.

8. táblázat

A külföldi állampolgárok száma a benyújtott szja-bevallás alapján, 2011-2015 (ezer fö)

\begin{tabular}{l|c|c|c|c|c}
\hline \multirow{2}{*}{ Megnevezés } & 2011. & 2012. & 2013. & 2014. & 2015. \\
\cline { 2 - 6 } & \multicolumn{3}{|c}{ év } \\
\hline $\begin{array}{l}\text { Munkavállalói jövedelem becslésénél alkalmazott szja-létszám } \\
\text { Munkavállalók hazautalásai becslésénél alkalmazott szja- } \\
\quad \text { létszám }\end{array}$ & 36,0 & 33,1 & 30,9 & 30,7 & 27,2 \\
\hline $\begin{array}{l}\text { Külföldi állampolgárok száma a benyújtott szja-bevallás } \\
\text { alapján }\end{array}$ & 46,6 & 45,4 & 45,8 & 46,9 & 49,6 \\
\hline
\end{tabular}

Az adókat és járulékokat a Magyarországon rezidens munkavállalókéval megegyező módon becsüljük. Egy legálisan hazánkban dolgozó külföldi állampolgár a bére után ugyanolyan mértékủ adót és járulékot fizet, mint egy magyar állampolgár.

Feltételezésünk szerint a nem regisztrált foglalkoztatottak száma és bére megegyezik a - külföldi állampolgárokra vonatkozó szja-bevallásból rendelkezésre álló regisztráltakéval, azonban ezen munkavállalók nem fizetnek adót és járulékot a jövedelmük után, tehát a munkavállalói jövedelmük megegyezik a nettó bérükkel.

Tételesen nem ismerjük azon külföldiek számát, akik részt vesznek az illegális kábítószer termelésben és kereskedelemben. A becsléséhez a drogból származó bruttó hozzáadott értékből indulunk ki, ezt teljes egészében vegyes jövedelemként számoljuk el. A külföldi állampolgárok részesedését a drogból származó jövedelemből az igazságügyi statisztikákban elérhető információk (kábítószerrel történő visszaélés büntettben a külföldi állampolgárok aránya) alapján becsüljük.

\subsection{A külföldre küldött munkavállalói hazautalások}

A tartósan, egy éven túl Magyarországon foglalkoztatott külföldi állampolgárok akik már magyar rezidensként vannak számon tartva - munkavállalói jövedelmének egy részét más országban élő hozzátartozójának hazautalhatja.

A becsléséhez szükséges egyik forrás a külföldi állampolgárok szja-bevallása. Azon külföldiek tartoznak ebbe a csoportba, akiket nem válogattunk le a munkavállalói jövedelem becslésénél ismertetett módszerrel. Meghatározzuk a hazautalás 
lehetőségével élő személyek számát, illetve az általuk jelentett béradatból becsüljük a hazautalás összegét.

Az adóbevallásokból rendelkezésre áll a tartósan Magyarországon dolgozók száma és bruttó bére, amelyből megállapítható az egy munkavállalóra jutó „kézhez kapott" jövedelem.

Az egy före jutó nettó bérekből és keresetekből levonjuk a magyar háztartások egy főre jutó végső fogyasztási kiadását (a KSH adatai alapján), majd ezt beszorozzuk az szja-bevallásból ismert létszámadattal. Ez a megtakarítás összege, mely egyben a hazautalás is.

Kísérleti számításokat végeztünk arra vonatkozóan, hogy amennyiben bizonyos bérkategória-csoportokhoz a bér nagyságrendjéhez társított végső fogyasztási kiadást rendelünk, vajon mennyivel tér el az így számított, jövedelemfüggő megtakarítások összege az átlagosan becsült értéktől. A kapott értékek meglepően hasonlítottak a jelenleg alkalmazott eljárás eredményeihez, ezért a továbbiakban is ezt követjük, a hazautalások megállapításához nem használunk korrekciót.

9. táblázat

A külföldre fizetett munkavállalói jövedelem és munkavállalói hazautalások, 2011-2015 (milliárd Ft)

\begin{tabular}{|c|c|c|c|c|c|}
\hline \multirow{2}{*}{ Megnevezés } & 2011. & 2012. & 2013. & 2014. & 2015 \\
\hline & \multicolumn{5}{|c|}{ év } \\
\hline $\begin{array}{l}\text { Magyarországon dolgozó külföldi rezidensek munkavállalói } \\
\text { jövedelme }\end{array}$ & 152,7 & 156,1 & 152,6 & 160,4 & 150,3 \\
\hline Külföldre küldött munkavállalói hazautalások & 29,8 & 33,2 & 34,6 & 36,0 & 38,4 \\
\hline
\end{tabular}

\section{Módszertani fejlesztések}

Tekintettel arra, hogy különösen a külföldön dolgozó magyar állampolgárok bérére, életvitelére vonatkozóan jelenleg nincs pontos, állandó, megbízható információs forrás, illetve adatgyüjtés, ezért a becslési eljárások finomítására van szükség. Ennek érdekében a forrásadatokat folyamatosan felülvizsgáljuk, pontosítjuk, de jelentős módszertani változtatásokra csak különösen indokolt esetben van mód.

A személyes hazautalások mutató meghatározásához a külkereskedelmi szolgáltatásként elszámolt külföldi munkavégzés célú turizmus és személyszállítás-adatok vizsgálata és beépítése folyamatban van. A mutató meghatározásához szükséges további tételek a külföld számlában rendelkezésre állnak. 
A magyarországi háztartások külföldről kapott hazautalásainak kismintás (körülbelül 3000 háztartás) felmérésére, „Családi segítségnyújtás” címmel, az MNB és a KSH projektjének keretében kerül sor. A magyar háztartások egy évnél rövidebb vagy hosszabb ideig külföldön élő és/vagy dolgozó hozzátartozóitól kapott pénzbeni és egyéb támogatásokra vonatkozó szokásait szeretnénk megismerni. A kérdőíven a hazautalás gyakoriságáról, módjáról (például készpénz, átutalás), az összeg felhasználási céljáról a küldő és a fogadó félről stb. kérdezünk. Erre vonatkozó publikáció 2018 folyamán várható. A projekt kapcsán információt kaphatunk tehát a külföldön egy évnél rövidebb, illetve hosszabb ideig munkát vállalók számáról és jövedelméről, valamint a magyar háztartástagoknak hazautalt összegekről.

\section{Summary}

The study presents the foreign segment of the Hungarian labour market (i.e. Hungarians working abroad and foreigners working in Hungary), including the settlement of compensation of employees and remittances. The estimation method and the recently used data sources are also discussed. 